\title{
ANTILISTERIAL ACTIVITY OF LACTIC ACID BACTERIA ISOLATED FROM VACUUM- PACKAGED BRAZILIAN MEAT AND MEAT PRODUCTS
}

\author{
Elaine C.P. De Martinis*; Márcia R.P. Públio; Priscila R. Santarosa; Flávia Z. Freitas \\ Faculdade de Ciências Farmacêuticas de Ribeirão Preto, Universidade de São Paulo, Ribeirão Preto, SP, Brasil.
}

Submitted: February 10, 2000; Returned to authors for corrections: June 06, 2000; Approved: January 18, 2001

\begin{abstract}
Twenty samples of Brazilian meat and meat products were screened by the agar overlay method for bacteriocinproducing lactic acid bacteria, using Lactobacillus sake ATCC 15521 as indicator strain. Based on Gram staining, $\mathrm{KOH}$ reaction, catalase test and fermentation of 49 carbohydrates (API $50 \mathrm{CH}$ ), three out of seven isolates with confirmed antagonist properties were identified as Lactobacillus curvatus, one as Leuconostoc mesenteroides and one as Leuconostoc sp. Two isolates could not be properly identified using these tests. The inhibitors produced by these strains were sensitive to proteases. Inhibition due to lytic bacteriophages was ruled out, so the isolates were classified as bacteriocin-producing lactic acid bacteria. Four of them presented antilisterial activity and a potential application as biopreservatives in meat systems.
\end{abstract}

Key words: lactic acid bacteria, meat, bacteriocins, biopreservation, Listeria monocytogenes

\section{INTRODUCTION}

Minimally processed refrigerated foods have been gaining consumer acceptance in the last years due to their "natural" appeal (16). However, the microbiological safety of these foods is of concern due to the possible presence of non-proteolitic strains of Clostridium botulinum able to grow at $4^{\circ} \mathrm{C}$ and the postprocessing contamination with psychrothophic pathogens, such as Listeria monocytogenes $(2,11)$.

Listeria monocytogenes is a Gram-positive bacterium that causes severe disease in immucompromised population (patients with chronic illnesses such as diabetes, cancer and AIDS), the elderly, pregnant women and newborns. Several large outbreaks of foodborne listeriosis have been reported worldwide and the fatality rate may be as high as 70\%. In Brazil, no outbreak has been reported, but Listeria monocytogenes has been isolated from a variety of foods $(7,31)$.

The use of saprophyte microorganisms and/or their metabolites to improve the microbiological safety or extend the shelf- life of foods is defined as biopreservation (27). The antagonistic properties of lactic acid bacteria allied to their safe history of use in fermentation processes make them very attractive to be used for biopreservation. Lactic acid bacteria produce antimicrobial substances such as lactic acid, diacetyl, hydrogen peroxide and bacteriocins (3).

Bacteriocins were defined by Montville and Kaiser (16) as ribossomaly synthetized antimicrobial peptides that are not lethal to the producing cells.

Nisin is the only bacteriocin approved for use in foods in roughly 50 countries (6). However, the application of nisin to meats is limited due to its low solubility at the meat $\mathrm{pH}$, its strong interaction with phospholipids leading to an uneven distribution of the bacteriocin in the food system and the inability of the producer strain (Lactococcus lactis subsp. lactis) to grow in meats (23).

Recently, Davies et al. (4) affirmed that nisin, at levels of 6.25 to $25 \mu \mathrm{g} / \mathrm{g}$, was effective to control the spoilage caused by lactic acid bacteria in vaccum-packaged Bologna meat, but the best results were obtained in products with the lowest fat content (25\%) and in the presence of an emulsifier (diphosphate).

According to Garcia et al. (8) and Mc Mullen and Stiles (14), lactic acid bacteria isolated from the same products where

\footnotetext{
* Corresponding author. Mailing address: Faculdade de Ciências Farmacêuticas de Ribeirão Preto, Universidade de São Paulo, Departamento de Análises Clínicas, Toxicológicas e Bromatológicas, Av. do Café s/n, CEP 14040-903, Ribeirão Preto, SP, Brasil. Fax: (+5516) 6331936, E-mail: edemart@ fcfrp.usp.br
} 
they are intended to be applied should present a competitive advantage compared to lactic acid bacteria from other sources.

Aiming to improve the microbiological safety of vaccumpackaged Brazilian meat products, we conducted a screening for bacteriocin-producing lactic acid bacteria and tested the ability of the isolates to inhibit the growth of Listeria monocytogenes.

\section{MATERIALS AND METHODS}

\section{Meat and meat products}

Ten kinds of meat and meat products were purchased at retail market in the city of Ribeirão Preto, São Paulo, Brazil. Two packages from the same batch of each product were bought, making an overall total of twenty samples. One package of each batch was analysed immediately after arrival at the laboratory and the other was tested after one week under refrigeration. The meat products included chicken breast, chicken sausage, pork sausage, ground beef and "mortadela" (a type of sausage) - one brand of each, hot dogs (three brands) and bacon (two brands).

\section{Isolation of bacteriocin-producing lactic acid bacteria}

The isolation procedure was the agar overlay method, according to Lewus et al. (12), with modifications. Fifty grams of sample were added to $450 \mathrm{~mL}$ of $0.1 \%$ peptone (Oxoid) and homogenized in a Bag Mixer (Interscience, France) for one minute. From the first homogenate $\left(10^{-1}\right.$ dilution $)$, serial decimal dilutions were prepared using the same diluent, and $0.1 \mathrm{~mL}$ was spread-plated on MRS agar plates (Oxoid) in duplicate. The plates were incubated at $25^{\circ} \mathrm{C}$ for 72 hours under anaerobiosis (Anaerogen AN25, Oxoid). One of the plates containing up to $100 \mathrm{CFU}$ was overlayed with the indicator culture (Lactobacillus sake ATCC 15521) and incubated at $25^{\circ} \mathrm{C}$ for 24 hours under anaerobiosis. The other MRS agar plate was kept under refrigeration (master plate). After incubation, the overlayed plates were observed for inhibition zones. The master plates from samples presenting inhibitory activity were replicated to Trypticase Soy Agar (Oxoid, without glucose) added of $0.6 \%$ yeast extract (Oxoid) - TSAYE, using a round piece of wood slightly smaller than the plate, covered with sterile velvet. The TSAYE plates were incubated for further 72 hours at $25^{\circ} \mathrm{C}$ under anaerobiosis. The overlay was repeated and the plates were incubated for $24 \mathrm{~h}$ at $25^{\circ} \mathrm{C}$ under anaerobiosis. Colonies showing inhibitory activity on TSAYE were transferred from the master plate to new MRS agar plates. These isolates were mantained at $-70^{\circ} \mathrm{C}$ in MRS broth (Oxoid) with $20 \%$ glycerol (Merck).

\section{Confirmation of the inhibitory activity and exclusion of inhibition due to lytic bacteriophages}

The cultures isolated on MRS agar were tested for bacteriocin production using the spot-on-the-lawn assay, according to Lewus et al. (12). To exclude the inibition due to the presence of lytic bacteriophages, one piece of agar from the inhibiton zone observed in the spot on the lawn assay was cut and tested according to Lewus et al. (12).

\section{Proteinaceus nature of the inhibitor}

Protease type XIV from Streptomyces griseus (Sigma) and $\alpha$-chymotripsin type II from bovine pancreas (Sigma) were used to test whether the inhibitor was a protein or not (12). Plates of spot on the lawn assay were prepared as described above and 20 $\mu \mathrm{l}$ of each protease solution at $20 \mathrm{mg} / \mathrm{ml}$ were spotted next to the producer strains, before the addition of the overlay containing the indicator microorganism. A control was prepared using sterile distilled water instead of protease solution.

\section{Identification of the isolates}

The morphology of the isolates was observed as a wet mount and after Gram staining, using an Olympus microscope under 1000x magnification. The cultures were also tested with $\mathrm{KOH}$ $3 \%$ according to Powers (21) and tested for the presence of catalase. Additionally, the pattern of fermentation of 49 carbohydrates was studied, using the API $50 \mathrm{CH}$ kit (BioMérieux).

\section{Spectrum of inhibitory activity}

Using the spot on the lawn assay (12), the antimicrobial activity of the lactic acid bacteria isolates was tested against eleven strains of Listeria monocytogenes isolated from chicken meat and one Escherichia coli (ATCC 29522) (Table 2).

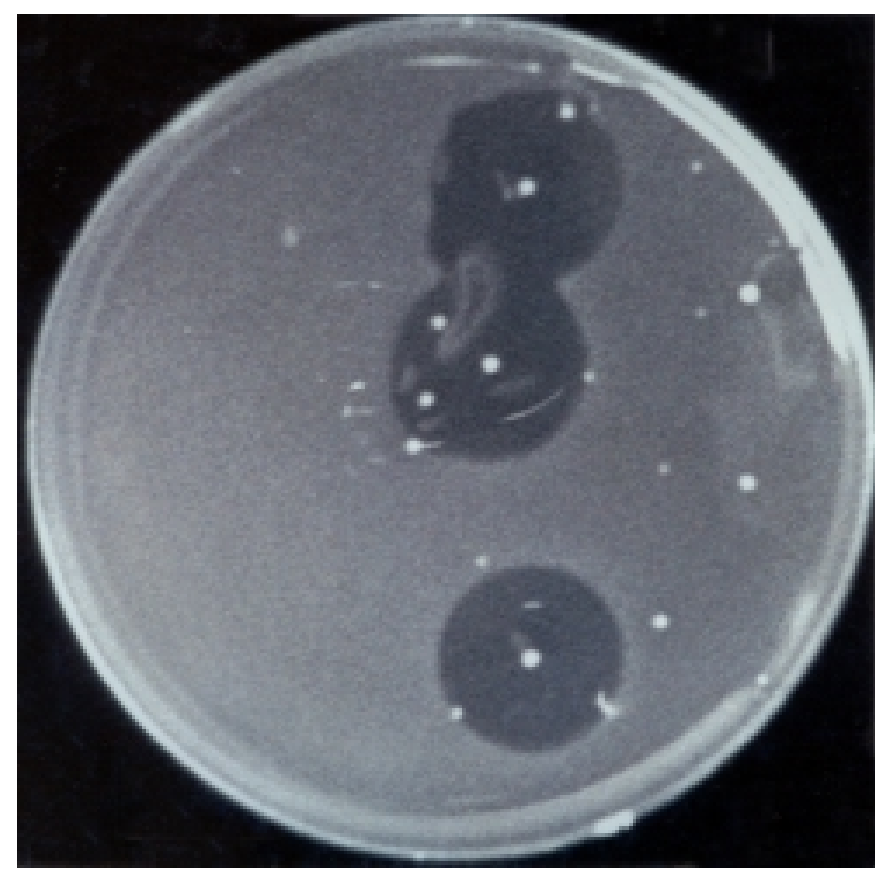

Figure 1: Inhibition zones observed on MRS agar plate from sample of hot-dog A (first sampling time, 10-1 dilution), using Lactobacillus sake ATCC 15521 as indicator microorganism. 
Table 1. Results of initial screening for bacteriocinogenic lactic acid bacteria.

\begin{tabular}{|c|c|c|c|c|}
\hline samples & $\begin{array}{l}\text { MRS TSAYE } \\
\text { halos halos }\end{array}$ & $\begin{array}{l}\text { spot on } \\
\text { the lawn }\end{array}$ & $\begin{array}{c}\text { Bacterio- } \\
\text { phages }\end{array}$ & $\begin{array}{l}\text { isolate } \\
\text { number }\end{array}$ \\
\hline$a^{*}$ & + & + & - & 11 \\
\hline
\end{tabular}

chicken

breast $b^{* *} \quad$ n.d. n.d. n.d. none

$\begin{array}{lllllll}\text { chicken } & \mathrm{a} & + & + & + & - & 12\end{array}$

sausage $\mathrm{b}+$ - n.d. n.d. none

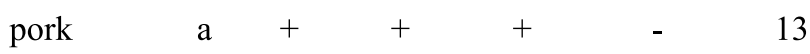

sausage $\quad \mathrm{b}+\mathrm{b}+\mathrm{C}_{-}+1$

ground a $+\quad+\quad-\quad$ n.d. none

beef

$\mathrm{b}+\quad+\quad-\quad$ n.d. none

$\begin{array}{lllllll}\operatorname{hot} \operatorname{dog} \mathrm{A} & \mathrm{a} & + & + & + & - & 14\end{array}$

$\mathrm{b}+\quad+\quad+\quad-5$

hot $\operatorname{dog} \mathrm{B} \quad$ a $\quad-\quad$ n.d. n.d. n.d. none

b - n.d. n.d. n.d. none

hot $\operatorname{dog} \mathrm{C} \quad \mathrm{a}+\quad-\quad$ n.d. n.d. n.d.

b - n.d. n.d. n.d. none

a $+\quad-\quad$ n.d. n.d. none

$\begin{array}{rlll}\operatorname{bacon} \mathrm{A} & \mathrm{b}+\text { n.d. n.d. none }\end{array}$

$\begin{array}{llllll}\mathrm{a} & + & + & + & - & 16\end{array}$

bacon $\mathrm{B}$

b $+\quad+\quad-\quad$ n.d. none

a $+\quad+\quad-\quad$ n.d. none

"mortadela"

b - n.d. n.d. n.d none

$*=$ tested upon arrival to the laboratory; $* *=$ tested after one week under refrigeration; n.d. $=$ not done

\section{RESULTS}

The results of the initial screening for bacteriocin-producing lactic acid bacteria strains are shown in Table 1. Fig. 1, related to the sample of hot $\operatorname{dog} \mathrm{A}$, illustrates the inhibition zones on MRS agar plates.
Table 2. Carbohydrate fermentation profile of lactic acid bacteria isolates.

\begin{tabular}{|c|c|c|c|c|c|c|c|}
\hline \multirow[b]{2}{*}{ characteristic } & \multicolumn{7}{|c|}{ LAB strain } \\
\hline & 1 & 5 & 11 & 12 & 13 & 14 & 16 \\
\hline glycerol & - & - & - & - & - & - & - \\
\hline erytritol & - & - & - & - & - & - & - \\
\hline D-arabinose & - & - & - & - & - & - & - \\
\hline L- arabinose & + & - & + & + & + & - & + \\
\hline ribose & + & + & + & - & + & + & + \\
\hline D-xylose & - & - & + & - & - & - & - \\
\hline L-xylose & - & - & - & - & - & - & - \\
\hline adonitol & - & - & - & - & - & - & - \\
\hline$\beta$ metyl xyloside & - & - & - & - & - & - & - \\
\hline galactose & + & + & - & - & + & + & + \\
\hline D glucose & + & + & + & + & + & + & + \\
\hline D fructose & + & + & + & + & + & + & + \\
\hline D mannose & + & + & + & + & + & + & + \\
\hline L-sorbose & - & - & - & - & - & - & - \\
\hline rhamnose & - & - & - & - & - & - & - \\
\hline dulcitol & - & - & - & - & - & - & - \\
\hline inositol & - & - & - & - & - & - & - \\
\hline manitol & - & - & - & ? & - & - & - \\
\hline sorbitol & - & - & - & - & - & - & - \\
\hline$\alpha$ metyl-D-manoside & - & - & - & - & - & - & - \\
\hline$\alpha$ metyl-D-glucoside & - & + & $?$ & + & - & + & - \\
\hline $\mathrm{N}$ acetyl-glucosamine & + & + & - & - & + & + & + \\
\hline amygdaline & $?$ & - & - & - & ? & - & - \\
\hline arbutine & + & - & - & ? & + & $?$ & + \\
\hline esculine & + & + & + & + & + & + & + \\
\hline salicine & + & + & - & ? & + & + & + \\
\hline cellobiose & + & + & + & + & + & + & $?$ \\
\hline maltose & - & + & + & + & - & + & - \\
\hline lactose & - & + & - & - & - & + & - \\
\hline melibiose & + & - & + & - & + & - & - \\
\hline saccharose & + & - & + & $?$ & + & + & + \\
\hline trehalose & - & + & + & + & - & + & - \\
\hline inuline & - & - & - & - & - & - & - \\
\hline melezitose & - & - & - & - & - & - & - \\
\hline D-raffinose & - & - & + & - & - & - & - \\
\hline starch & - & - & - & - & - & - & - \\
\hline glycogene & - & - & - & - & - & - & - \\
\hline xylitol & - & - & - & - & - & - & - \\
\hline$\beta$ gentibiose & - & - & - & ? & - & - & - \\
\hline D-turanose & - & - & + & + & - & + & - \\
\hline D-lyxose & - & - & - & - & - & - & - \\
\hline D-tagatose & - & - & - & - & - & - & - \\
\hline D-fucose & - & - & - & - & - & - & - \\
\hline L-fucose & - & - & - & - & - & - & - \\
\hline D-arabitol & - & - & - & - & - & - & - \\
\hline L-arabitol & - & - & - & - & - & - & - \\
\hline gluconate & - & - & - & $?$ & - & - & - \\
\hline 2 ceto-glucc & - & - & - & - & - & - & - \\
\hline 5 ceto-gluconate & - & - & - & - & - & - & - \\
\hline
\end{tabular}

+ = positive; - = negative; = doubtful. 
Table 3. Sizes of the inhibition zones presented by the LAB strains against $L$. sake, L. monocytogenes and E. coli.

\begin{tabular}{lccccccc}
\hline & \multicolumn{7}{c}{ LAB strain } \\
\cline { 2 - 8 } indicator microorganism & 1 & 5 & 11 & 12 & 13 & 14 & 16 \\
\hline Lactobacillus sake & 1.1 & 0.9 & 1.1 & 0.7 & 1.0 & 1.0 & 1.2 \\
L. monocytogenes 1 & 0.9 & 0.0 & 1.0 & 0.0 & 1.0 & 0.0 & 0.8 \\
L. monocytogenes 2 & 1.0 & 0.0 & 1.0 & 0.0 & 0.9 & 0.0 & 0.5 \\
L. monocytogenes 7 & 0.9 & 0.0 & 1.0 & 0.0 & 1.0 & 0.0 & 0.7 \\
L. monocytogenes 8 & 0.9 & 0.0 & 1.0 & 0.0 & 1.0 & 0.0 & 0.6 \\
L. monocytogenes 10 & 1.2 & 0.0 & 1.0 & 0.0 & 1.3 & 0.0 & 1.1 \\
L. monocytogenes 124 & 1.0 & 0.0 & 1.0 & 0.0 & 1.1 & 0.0 & 0.9 \\
L. monocytogenes 126 & 0.8 & 0.0 & 1.0 & 0.0 & 1.0 & 0.0 & 0.5 \\
L. monocytogenes 128 & 1.4 & 0.0 & 1.1 & 0.0 & 1.5 & 0.0 & 1.1 \\
L. monocytogenes 129 & 1.4 & 0.0 & 0.9 & 0.0 & 1.5 & 0.0 & 1.2 \\
L. monocytogenes 134 & 1.0 & 0.0 & 1.0 & 0.0 & 1.1 & 0.0 & 0.9 \\
L. monocytogenes 135 & 1.2 & 0.0 & 1.0 & 0.0 & 1.3 & 0.0 & 1.0 \\
Escherichia coli & 0.0 & 0.0 & 0.0 & 0.0 & 0.0 & 0.0 & 0.0 \\
\hline
\end{tabular}

* measured from the center of the producer spot to the border of inhibition zone $(\mathrm{cm})$.

Results of confirmatory assay for inhibitory activity and exclusion due to lytic bacteriophages are also shown in Table 1. All the inhibitors produced by the isolates were destroyed by $\alpha$-chymotripsin and protease of Streptomyces griseus.

Seven strains, considered as bacteriocin-producing lactic acid bacteria, isolated from chicken breast, chicken sausage, pork sausage, hot dog and bacon (Table 1), were Gram positive and catalase negative. Isolates \# $1,5,13,14$ and 16 were homofermentative rods, whereas \# 11 and 12 were heterofermentative cocci.

Table 2 presents the carbohydrate fermentation patterns of the isolates. According to these tests, strains \# 1 and 13, isolated from pork sausage, could not be successfully identified. Isolates \# 5, 14 and 16 were identified as Lactobacillus curvatus, isolate \# 11 as Leuconostoc mesenteroides and isolate \# 12 as Leuconostoc sp.

Table 3 shows the sizes of the inhibition zones against the indicators Lactobacillus sake ATCC 15521, Escherichia coli ATCC 29522 and eleven food isolates of Listeria monocytogenes, as detected by the spot on the lawn test.

\section{DISCUSSION}

The screening experiments with MRS agar plates showed that five out of twenty meat and meat products samples did not present colonies with inhibitory activity. Incubation under anaerobiosis was important to prevent the growth of molds and to minimize the production of hydrogen peroxide. The temperature of $25^{\circ} \mathrm{C}$ was chosen to allow growth of either mesophylic or psychotrophic bacterial strains.

Due to the difficulty to observe the inhibition zones, only plates with no more than $100 \mathrm{CFU}$ were selected for overlay. Similar approach was taken by Pilet et al. (20), who selected plates with even less colonies (30 CFU), but Lewus et al. (12) chose plates containing from 30 to $300 \mathrm{CFU}$ to be overlayed with the indicator strain.

What concerns the shape of the inhibiton zones, our results agree partially with Ahn and Stiles (1). These authors reported diffuse inhibition zones when using MRS agar, lacking a clear cut between growth and no growth of the indicator culture. The diffuse inhibition zones are probably due to acid production from glucose in MRS agar. However, as shown in Fig. 1, for some samples, even when MRS agar was used, inhibition zones were well defined.

TSAYE medium does not contain glucose and the inhibition due to acid production is prevented in it. When MRS agar plates of 15 samples showing inhibition zones were replicated to TSAYE plates, the number of samples presenting inhibitory colonies was reduced to 12 .

The inhibitory activity of those colonies was confirmed using the spot on the lawn assay and Lactobacillus sake ATCC 15521 as the indicator strain. Seven strains with antagonistic properties, isolated from chicken breast, chicken sausage, hot dog and bacon (Table 1), were successfully purified from the master plates. As shown in Table 3, the isolates presented inhibition zones in the range of $0.7 \mathrm{~cm}$ (strain \# 12, from chicken sausage) to $1.2 \mathrm{~cm}$ (strain \# 16, from bacon).

Montville and Kaiser (16) suggested that the proteinaceous nature of the inhibitor could be demonstrated by the negation of inhibition zone in the presence of proteases. For all isolates, we observed a dimple of growth when proteases were spotted near the inibition zone in the spot on the lawn assay. These results show that the inhibitory compounds were destroyed by protease from Streptomyces griseus and by $\alpha$-chymotripsin, and consequently, considered proteins.

The method proposed by Lewus et al. (12) was useful to rule out the inhibition due to lytic bacteriophages because bacteriocins do not posses genetic determinants for auto-replication in susceptible hosts, but bacteriophages do (13).

The seven bacteriocinogenic isolates were preliminarly identified using Gram staining, $\mathrm{KOH}$ reaction, catalase test and gas production from glucose. All the seven strains were Gram positive, catalase negative and $\mathrm{KOH}$ negative. According to Powers (21), the cell wall of Gram negative bacteria is destroyed by $\mathrm{KOH} \mathrm{3 \%}$ and the solution becomes viscous due to the release of fragments of DNA. Gram positive organisms are not affected and a negative reaction for $\mathrm{KOH}$ confirms that the isolate is Gram positive. Heterofermentative metabolism was detected in coccoid cultures \# 11 and \# 12. Strains \# 1, 5, 13, 14 and 16 were rods and did not produce gas from glucose. Our findings were consistent with those of Holzapfel (10) who observed that 84.9\% of the lactic acid bacteria isolated from vaccum-packaged meat were homofermentative rods.

The API 50 CH kit was helpful to identify the lactic acid bacteria isolated in this work (Table 2). The isolates \# 1 and 13 yielded the same fermentation profile and were considered as the same strain. 
Lewus et al. (12) also reported the multiple isolation of a bacteriocinogenic strain. The identification of this isolate was not possible due to a doubtful profile obtained in API $50 \mathrm{CH}$.

For strain \# 5, API $50 \mathrm{CH}$ yielded a very good identification and the strain was classified as Lactobacillus curvatus. The results were also in accordance to the biochemical characteristic described by Schillinger and Lücke (24) for this species (ribose positive, melibiose negative, maltose positive). Strain \# 14 was also identified as Lactobacillus curvatus, but the fermentation pattern was slightly different from strain \# 5. Strain \# 16 was also classified as Lactobacillus curvatus.

Among heterofermentative isolates, strain \# 12 was detected to belong to the genus Leuconostoc (Table 2), but the species could not be determined. Strain \# 11 was successfully identified as Leuconostoc mesenteroides.

Due to recent advances in genetic techniques, Stiles and Holzapfel (28) stated that there is a need for intense studies considering phenotypic and phylogenetic characteristics, for taxonomy of lactic acid bacteria.

The frequency of isolation of bacteriocin producing strains observed in this work was around 30\% (seven strains isolated from 20 samples). Pilet et al. (20) reported the isolation of four bacteriocinogenic strains from 20 samples of fish, and Lewus et al. (12) isolated ten bacteriocin-producing lactic acid bacteria from eleven cuts of raw meat analysed at weekly intervals for up to three weeks. This variation in the frequency of isolation can be attributed to intrinsic differences of samples and to the diversity of indicator microorganisms used for initial screening.

The screening for bacteriocinogenic lactic acid bacteria using culture collection strains generally are less sucessful than screening from foods. Moreno et al. (18) reported that $8.4 \%$ of 167 strains of a culture collection were able to inhibit all the indicator microorganisms studied and Hastings et al. (9) isolated five bacteriocin-producing lactic acid bacteria from 139 cultures.

Strains \# 1, 11, 13 and 16 were able to inhibit all the strains of Listeria monocytogenes studied. In spite of the uncertainity of the taxonomical position of Listeria, the relatedness to the family Lactobacillaceae may explain their antilisterial activity $(2,32$, 33). Strains \# 1 and 13 were the more inhibitory followed by strains \# 11 and 16. The most pronounced inhibition was observed against L. monocytogenes 128 and 129. Ukuku and Shelef (30) conducted experiments that clearly demonstrated that the effects of the bacteriocin nisin to Listeria monocytogenes were strain dependent. Our results also indicate that there is a differential sensitivity to bacteriocins among Listeria monocytogenes strains.

None of the isolates was able to inhibit growth of Escherichia coli. This finding confirms the narrow spectrum of activity of the inhibitors, as stated by Tagg et al. (29) when defining bacteriocins of Gram positive bacteria. Stevens et al. (27) theorized that bacteriocins of lactic acid bacteria are inefficient to inhibit Gram negative organisms because the outer membrane hinders the site for bacteriocin action, which is the cell membrane (17).
Despite the lack of antilisteriae activity of strains \# 5, 12 and 14, they have a potential to be used as an additional hurdle for controlling spoilage process in vacuum-packaged meats, specially the homofermentative strains \# 5 and 14.

\section{ACKNOWLEDGEMENTS}

This work was supported by a research grant from Fundação de Amparo à Pesquisa do Estado de São Paulo (1998/107592). The authors are grateful to Prof. Maria Teresa Destro, Ph.D., from Faculdade de Ciências Farmacêuticas, Universidade de São Paulo, for donating Listeria monocytogenes strains.

\section{RESUMO}

\section{Atividade antilisterial de bactérias láticas isoladas de carnes e produtos cárneos brasileiros embalados à vácuo}

Vinte amostras de carnes e produtos cárneos brasileiros foram analisadas com a finalidade de se isolar bactérias láticas produtoras de bacteriocina, através do método de antagonismo em ágar, utilizando Lactobacillus sake ATCC 15521 como microrganismo indicador. Baseado na coloração de Gram, reação com $\mathrm{KOH}$, teste de catalase e teste de fermentação de 49 carboidratos (API $50 \mathrm{CH}$ ), três das sete cepas com características antagonísticas foram classificadas como Lactobacillus curvatus, uma como Leuconostoc mesenteroides e uma como Leuconostoc sp. Duas cepas não puderam ser identificadas usando apenas estes testes. Os inibidores produzidos por essas cepas mostraram-se sensíveis a proteases. A inibição devido a bacteriófagos líticos foi descartada e assim as culturas foram classificadas como bactérias láticas produtoras de bacteriocina. Quatro cepas apresentaram atividade antilisterial, e conseqüentemente um potencial de utilização como bioconservadores em produtos cárneos.

Palavras-chave: bactérias láticas, carnes, bacteriocinas, bioconservadores, Listeria monocytogenes

\section{REFERENCES}

1. Ahn, C.; Stiles, M.E. Antibacterial activity of lactic acid bacteria isolated from vacuum-packaged meats. J. Appl. Bacteriol., 69: 302-310, 1990.

2. Crandall, A.D.; Winkowski, K.; Montville, T.J. Inability of Pediococcus pentosaceus to inhibit Clostridium botulinum in sous vide beef with gravy at 4 and 10 ${ }^{\circ}$ C. J. Food Prot., 57: 104-107, 1994.

3. Daeschel, M.A. Antimicrobial substances from lactic acid bacteria for use as food preservatives. Food Technol., 43 (1): 164-167, 1989.

4. Davies, E.A.; Milne, C.F.; Bevis, H.E.; Potter, R.W.; Harris, J.M.; Willians, G.C.; Thomas, L.V.; Delves-Broughton, J. Effective use of nisin to control lactic acid bacterial spoilage in vacuum-packed bologna-type sausage. $J$. Food Prot., 62: 1004-1010, 1999. 
5. De Martinis, E.C.P.; Franco, B.D.G.M. Inhibition of Listeria monocytogenes in a pork product by a Lactobacillus sake strain. Int. J. Food Microbiol., 42: 119-126, 1998.

6. Delves-Broughton, J.; Blackburn, P.; Evans, R.J.; Hugenholtz, J. Applications of the bacteriocin, nisin. Antonie van Leewenhoek, 69: 193201, 1996.

7. Franco, B.D.G.M.; Landgraf, M. Microbiologia dos Alimentos. Atheneu: São Paulo, 1996, 182p.

8. Garcia, T.; Martin, R.; Sanz, B.; Hernández, P.E.; Revisión: extensión de la vida útil de la carne fresca. I: envasado en atmósferas modificadas y utilización de bactérias lácticas y bacteriocinas. Rev. Esp. Cienci. Tecnol. Aliment., 35(1):1-18, 1995.

9. Hastings, J.W.; Gibson, P.T.; Chauhan, R.; Dykes, G.A.; Von Holy, A. Similarity of bacteriocins from spoiled meat lactic acid bacteria. South African J. Sci., 92 (8): 376-380, 1996.

10. Holzapfel, W.H. The Gram positive bacteria associated with meat and meat products. In: Davies, A.; Board, R. (eds.) The microbiology of meat and poultry. Blackie Academic \& Professional, London, 1998, p.35-84.

11. Hugas, M. Bacteriocinogenic lactic acid bacteria for the biopreservation of meat and meat products. Meat Sci., 49 (suppl. 1): S139-S150, 1998.

12. Lewus, C.B.; Kaiser, A.; Montville, T.J. Inhibition of food-borne bacterial pathogens by bacteriocins from lactic acid bacteria isolated from meat Appl. Environ. Microbiol., 57: 1683-1688, 1991.

13. Mayr-Harting, A.; Hedges, A.J.; Berkeley, R.C.W. Methods for studying bacteriocins. In: Norris, J.R.; Ribbons, D.W. (eds.) Methods in Microbiology, v.7a. Academic Press, New York, 1972, p.313-342.

14. Mc Mullen, L.M.; Stiles, M.E. Potential for use of bacteriocin-producing lactic acid bacteria in the preservation of meats. J. Food Prot., 59 (suppl.): 64-71, 1996.

15. Montville, T.J.; Winkowski, K.; Ludescher, R.D. Models and mechanisms for bacteriocin action and application. Int. Dairy J., 5: 797-814, 1995.

16. Montville, T.J.; Kaiser, A. Antimicrobial proteins: classification, nomenclature, diversity and relationship to bacteriocins. In: Hoover, D.G. Steenson, L.R. (eds). Bacteriocins of lactic acid bacteria. Academic Press: New York: 1993, p.1-22.

17. Montville, T.J.; Winkowski, K. Biologically based preservation systems and probiotic bacteria. In: Doyle, M.P.; Beuchat, L.R.; Montville, T.J. (eds) Food Microbiology: fundamentals and frontiers. ASM Press, Washington, 1997, p.557-577.

18. Moreno, I.; Lerayer, A.L.S.; Leitão, M.F.F. Detection and characterization of bacteriocin-producing Lactococcus lactis strains. Rev. Microbiol., 30: 130-136, 1999.
19. Muriana, P.M. Bacteriocins for control Listeria spp. in food. J. Food Prot., 55: 337-343, 1992

20. Pilet, M-F.; Dousset, X.; Barré, R.; Novel, G.; Desmazeaud, M.; Piard, J-C. Evidence for two bacteriocins produced by Carnobacterium piscicola and Carnobacterium divergens isolated form fish and active against Listeria monocytogenes. J. Food Prot., 58: 256-262, 1995.

21. Powers, E.M. Efficacy of the RYU nonstaining KOH technique for rapidly determining Gram reaction of food-borne and waterborne bacteria and yeasts. Appl. Environ. Microbiol., 61: 3756-3758, 1995.

22. Rocourt, J.; Cossart, P. Listeria monocytogenes. In: Doyle, M.P.; Beuchat, L.R.; Montville, T.J. Food Microbiology: fundamentals and frontiers. ASM Press: Washington, 1997, p.76-78.

23. Schillinger, U.; Geisen, R.; Holzapfel, W.H. Potential antagonistic microorganisms and bacteriocins for the biological preservation of foods. Trends Food Sci. Technol., 7:158, 1996.

24. Schillinger, U.; Lücke, F-K. Identification of lactobacilli from meat and meat products. Food Microbiol., 4: 199-208, 1987.

25. Shewfelt, R.L. Quality of minimally processed fruits and vegetables. J. Food Qual., 10 (3): 143-156, 1987.

26. Stevens, K.A.; Sheldon, B.W.; Klapes, N.A.; Klaenhammer, T.R. Nisin treatment for inactivation of Salmonella species and other Gram-negative bacteria. Appl. Environ. Microbiol., 57: 3613-3615, 1991.

27. Stiles, M.E.; Hastings, J.W. Bacteriocin production by lactic acid bacteria: potential for use in meat preservation. Trends Food Sci. Technol., 2: 247$251,1991$.

28. Stiles; M.E.; Holzapfel, W.H. Lactic acid bacteria of foods and their current taxonomy. Int. J. Food Microbiol., 36: 1-29, 1997.

29. Tagg, J.R.; Dajani, A.S.; Wannamaker, L.W. Bacteriocins of Gram positive bacteria. Bacteriol. Rev., 40: 722-756, 1976.

30. Ukuku, D.O.; Shelef, L.A. Sensitivity of six strains of Listeria monocytogenes to nisin. J. Food Prot., 60: 867-869, 1997.

31. Varnam, A.H.; Evans, M.G. Foodborne pathogens: an illustrated text. Mosby Year Book: Saint Louis, 1991, p.330-335.

32. Wilkinson, B.J.; Jones, D. A numerical taxonomic survey of Listeria and related bacteria. J. Gen. Microbiol., 98: 399-421, 1977.

33. Winkowski, K.; Montville, T.J. Use of meat isolate, Lactobacillus bavaricus $\mathrm{MN}$, to inhibity Listeria monocytogenes growth in model meat gravy system. J. Food Saf., 13: 19-31, 1992.

34. Yang, R.; Ray, B. Prevalence and biological control of bacteriocinproducing psychrotrophic leuconostocs associated with spoilage of vacuum-packaged processed meats. J. Food Prot., 57: 209-217, 1994. 